\title{
Does soil applications of fulvic acid applied with potassium sulphate influence mango fruit quality?
}

\author{
Paula Ibell ${ }^{1, a}$, Ian Bally ${ }^{1}$, Carole Wright ${ }^{1}$ and Cheryldene Maddox ${ }^{1}$
}

Department of Agriculture, Fisheries and Forestry, 28 Peters St, Mareeba, Qld, Australia

\begin{abstract}
The effect of fulvic acid as a supplement to potassium (K) applications on mango fruit quality, flower synchronisation and yield were investigated in an 8 year-old Kensington Pride (KP) orchard over two seasons, at South-edge Research Station, in Far North Queensland. The aim of the trial was to determine if fulvic acid (FA) improved the efficiency of potassium uptake. Experimental treatments included i) nil $\mathrm{K}+$ nil FA, ii) $800 \mathrm{~g} \mathrm{~K}$ per tree, and iii) $800 \mathrm{~g} \mathrm{~K}+300 \mathrm{ml} \mathrm{FA}$ per tree. Treatments were applied approximately every three weeks, after fruit set and during the fruit filling stage through to harvest. Treatment effects were assessed by measuring tree yield, fruit weight, length, depth and width, the incidence of post-harvest disease, ground skin colour at eating-ripe stage, as well as the proportion of canopy flowering in different stages in the following season. Results indicated that neither $\mathrm{K}$ fertiliser nor FA increased average fruit number or yield. In the first year, K combined with FA significantly increased the proportion of fruit with no lenticel spotting and the lightness of the ground skin colour of eating-ripe mangoes. By the second season, $\mathrm{K}$ with or without FA significantly increased the average fruit length and foliar dry matter $\mathrm{K}$ concentration while fruit weight was only marginally increased when compared to the nil $\mathrm{K}$ treatment. In summary, the addition of $\mathrm{K}$ applied during fruit development led to improved fruit size and maintenance of foliar K concentrations two years after application. However, although the addition of $\mathrm{FA}$ with $\mathrm{K}$ fertiliser reduced the proportion of fruit with lenticel spotting, this result was only observed in the first season of the trial and hence would require further research to confirm.
\end{abstract}

Keywords: mango, organic ameliorants, fulvic acid, fruit quality, fruit size

\section{INTRODUCTION}

There are currently an increasing range of organic products available for growers including a range of humic acid products. Fulvic acid (FA) is described as the smallest molecular size, humic pool ( $<3500 \mathrm{Da}$ ) (Nardi et al. 2002) and it is claimed to be the most effective humic fraction for influencing plant growth (Piccolo et al. 1992). Humic substances with low molecular weights have been shown to help increase the solubility of nutrients and some enzymes which both have direct and indirect effects on plant growth (Edwards and Arancon 2004). The mechanisms behind these effects are related to the direct uptake of

a Email: Paula.Ibell@daf.qld.gov.au 
macromolecules through the plasma membrane of the roots which are then translocated through the plant, influencing the metabolism within plant cells (Chen et al. 2004). Alternatively there may be some relationship between the presence of micro-organisms in the soil and their release of hormones and the increase of these hormones in the soil substrate being available for plant growth (Nardi et al. 2002). The aim of this trial was to determine if FA improved the efficiency of potassium uptake or fruit quality when applied to a sandy loam soil type in Far North Queensland.

\section{MATERIALS AND METHODS}

The effect of FA as a supplement to potassium (K) applications on mango fruit quality, flower synchronisation and yield were investigated over two seasons in an 8 year-old Kensington Pride orchard at South-edge Research Station, in Far North Queensland. Experimental treatments included the application of i) nil $\mathrm{K}+$ nil FA, ii) $1000 \mathrm{~g} \mathrm{~K}$, and iii) $1000 \mathrm{~g} \mathrm{~K}+300 \mathrm{ml} \mathrm{FA}$ (Label recommends 10L/ hectare (ha) FA) on an individual tree basis as split doses. Trees spacing was at $8 \mathrm{~m}$ by $8 \mathrm{~m}$, with trees planted at 156 trees per ha. FA was applied as a drench diluted in $9 \mathrm{~L}$ of water, prior to broadcast $\mathrm{K}$ fertilization, both within the drip-line of the tree. Potassium fertiliser was applied as potassium sulphate between August and December each year, where five applications of $200 \mathrm{~g}$ of potassium sulphate was applied approximately three weeks apart from fruit set, through to harvest as a direct soil application. Nitrogen fertiliser was applied after harvest as 156 grams/tree of urea as outlined in the Agrilink Mango Growers Guide for 2-6 m diameter KP trees (Muerant et al. 1999). Two Kg of gypsum, 500g of magnesium sulphate and 40 grams of boron was also applied in 2012 and 2013 to each of the trees after harvest and pruning. Trace elements were applied as a 1\% foliar spray in July 2012 and 2013 as zinc sulphate heptahydrate, Iron chelate and solubor.

\section{Experimental design}

The experiment was carried out at an established mango orchard at Southedge Research Station. 30 trees were selected from the orchard, and each of the three treatments was replicated 10 times and set out as a randomised complete block design with single tree plots.

\section{Foliar nutrition}

Soils were characterised at the start of the experiment (data not included). Foliar $\mathrm{K}$ and other micro and macro nutrient dry matter concentrations were assessed in June 2013 and 2014. Initial foliar $\mathrm{K}$ dry matter (DM) \% was $0.84 \%$ (which is within the adequate range for foliar $\mathrm{K}$ ) while soil $\mathrm{K}$ was $0.14 \mathrm{meq} / 100 \mathrm{~g}$ at $0-50 \mathrm{~cm}$ soil depth and $0.16 \mathrm{meq} /$ $100 \mathrm{~g}$ at $50-80 \mathrm{~cm}$ depth which is below the desirable level in soil which is $0.37 \mathrm{meq} / 100 \mathrm{~g}$ $\mathrm{K}$.

\section{Yield and canopy measurements}

Total tree yield was estimated from counts of fruit numbers in on the 10 replicate trees per treatment, prior to harvest and the average fruit weight was based on 5-10 fruit from each tree at harvest. Total yield per hectare was then estimated by multiplying the total tree yield $(\mathrm{kg}$ ) by trees per hectare (156 trees per ha) and divided by 1000 (conversion from $\mathrm{Kg}$ to tonnes). Tree canopy volume $(\mathrm{V})\left(\mathrm{m}^{3}\right)$ and canopy surface area $(\mathrm{CSA})\left(\mathrm{m}^{2}\right)$ were estimated using the calculations $V=\pi r^{2} h$ and $C S A=\pi r^{2}$ respectively. Yield efficiency was 
calculated as the total tree yield divided by the canopy volume (V). Tree height, skirt height, canopy width and length were also measured in June each year once vegetative growth had ceased, while canopy height was calculated as tree height minus skirt height.

\section{Fruit quality measurements}

Fruit was harvested on the 17th of December 2012 and 31st of December 2013. At harvest 5-10 fruit from each tree was collected and returned to the Centre for Tropical Agriculture in Mareeba for processing. Once back at the facility, mangoes were de-sapped with a bucket of water and mango wash, hot water dipped to $52 \circ \mathrm{C}$ and then dried and placed back into labelled boxes in a ripening room set at $22 \circ \mathrm{C}$. Fruit were ripened to eatingripe and then assessed for ground, skin colour, the percentage of fruit with zero incidence of lenticel spotting (\%) and severity of disease incidence ( $\mathrm{cm} 2)$ (results not shown). Prior to eating, ripe fruit were measured for fruit dimensions (length, width and depth) and individually weighed. Assessment for ground skin colour (Red Green Blue spectrum) was undertaken in 2013, using a Konica Minolta spectrophotometer while in the second year of fruit quality assessments colour was assessed using skin colour classes in the Mango Quality assessment manual (Holmes et al. 2009). Lenticel spotting was also assessed using the classes in the Mango Quality assessment manual (Holmes et al. 2009).

\section{Flowering synchronisation}

To identify if application of $\mathrm{K}$ at different times prior to harvest had any effect on flowering in the season following $\mathrm{N}$ applications, a whole tree flower assessment method was used.

\section{Whole tree flower assessment}

In 2013, a whole tree flower survey assessment method was used to assess the effect of treatment on flower synchronisation. In this assessment the canopy is arbitrarily divided into four quarters representing north, south, east and west quarters of the tree. A count of the number of inflorescences in different flowering stages was then estimated. The flower development stages were grouped as stages A-C, D-G, H-J and K (see paper by Ibell et al. $2014 \mathrm{a}$, in this proceeding for an explanation of these flowering stages). At time 3 the number of bronzed new vegetation and inflorescences with leaves were also counted. The proportion of the terminals in each quarter was analysed using a binomial generalised linear mixed model (GLMM) to investigate the effect of treatment, tree quarter and their interaction.

\section{RESULTS AND DISCUSSION}

Results indicated that neither $\mathrm{K}$ fertiliser nor $\mathrm{K}$ with FA increased average inflorescence number in the canopy (2013)(mean 149-160 inflorescences per tree, $\mathrm{p}=0.787$ ), fruit number per tree (mean for $2013,108-111$ fruit per tree, $\mathrm{p}=0.994$ ); mean for 2014, 114-125.2 fruit per tree ( $p=0.206)$ ), nor total tree or orchard yields (mean for 2013 53.3-59. kg per tree $(\mathrm{p}=0.090)$ and 8.3-9.2 tonnes per ha $(\mathrm{p}=0.090)$; and mean for 2014 58.7-62.9 kg per tree ( $p=0.945)$ and 9.1-9.8 tonnes per ha, $(\mathrm{p}=0.945)$. In the first year, $\mathrm{K}$ combined with FA significantly increased the proportion of fruit with zero lenticel spotting and the lightness of the ground skin colour of eating ripe mangoes (Table 1). The proportion of mango with zero lenticel occurrence was not significantly different in 2014 
$(\mathrm{p}=0.774)$. By the second season, $\mathrm{K}$ with or without FA significantly increased the average fruit length and foliar dry matter K concentration while fruit weight was only marginally increased when compared to the nil K treatment (Table 2). For flower synchronisation there was a significant effect of quarter $(\mathrm{p}=0.025)$ but not treatment, at time 3 where the west quarter $(0.05)$ having a significantly higher proportion of inflorescences at flowering stage A-C terminals compared to the east (0.01) and south (0.02) quarters.

\section{CONCLUSIONS}

In summary, it was the addition of $\mathrm{K}$ fertilizer applied during fruit development that led to improved fruit size and maintenance of foliar $\mathrm{K}$ concentrations after two years of $\mathrm{K}$ application. Despite other research results that have found that the application of some humic products increased mango fruit size and yield (El-Kosary et al. 2011, Silva et al. 2010) this was not the case in this experiment under these environmental conditions. It is possible that the FA rate in this experiment could have influenced these results and as a result wider experimentation is warranted. While these results found applications of fulvic acid reduced the proportion of fruit with lenticel spotting, this result was only observed in the first season of this trial and hence would also require further research to confirm. Fulvic acid applications did not show any other benefits to fruit quality or flowering.

\section{ACKNOWLEDGEMENTS}

The authors wish to acknowledge the funding support by the Australian Centre for Agricultural Research (ACIAR) for operating funds to complete this research. We also acknowledge the Qld Department Agriculture and Fisheries staff and casuals involved in maintenance of the orchards and those whom assisted with data collection during this trial.

\section{Literature cited}

Chen, Y., De Nobili, M., Aviad, T., (2004) Stimulatory effects of humic substances on plant growth (Chapter 4) In Soil organic matter in Sustainable Agriculture. Magdoff, F., Weil, R.R. (Eds). CRC Press, Boca Raton.

Edwards, C.A., Arancon, N.Q. (2004) Interactions among organic matter, earthworms and microorganisms in promoting plant growth (Chapter 1) In Soil organic matter in Sustainable Agriculture. Magdoff, F., Weil, R.R. (Eds). CRC Press, Boca Raton.

El-Kosary, S. El-Shenawy, I.E, Radwan, S.I. (2011) Effects of microelements, amino and humic acids on growth, flowering and fruiting of some Mango cultivars. J. Hort. Sci. \& Ornamental Plants. 3 (2): 152-161, 2011.

Holmes, R., Hofman, P., Barker, L. (2009). Mango quality assessment manual. A guide to assessing the postharvest quality of Australian Mangoes. State of Queensland, Department of Economic Development and Innovation. Brisbane.

Muerant, N., Kernot, I. (1998). Mango Information Kit. The State of Queensland, Department of Primary Industries, Brisbane.

Nardi, S., Pizzeghello, D., Muscolo, A., Vianello, A. (2002) Physiological effects of humic substances on higher plants. Soil Biol. Biochem. 34: 1527-1536.

Piccolo, A., Nardi, S., Concheri, G. (1992) Structural characteristics of humic substances as related to nitrate uptake and growth regulation in plant systems. Soil Biol. Biochem. 24 (4):373-380.

Silva, G.J.N., Souza, E.M., Martins, R.S. (2010) Influence of nutritional management of mango Mangifera Indica L. fruit quality. XXI Congresso, Brasileiro de Agricultura, Natal. 
Table 1: Fruit colour and proportion of fruit with zero lenticel spot class KP variety in 2013. \# SED is not presented as it is calculated on the logit scale.

\begin{tabular}{llll}
\hline & & Background skin-colour & Lenticel spot 2013 \\
Year & Treatment & Lightness & Zero spots (\%) \\
\hline \multirow{2}{*}{$2012-13$} & (1) Control & $63.5 \mathrm{ab}$ & $7 \mathrm{a}$ \\
& $(2) \mathrm{K}_{2} \mathrm{SO}_{4}$ & $62.7 \mathrm{a}$ & $11 \mathrm{ab}$ \\
& (3) $\mathrm{K}_{2} \mathrm{SO}_{4}+\mathrm{FA}$ & $64.38 \mathrm{~b}$ & $21 \mathrm{~b}$ \\
& p-value & 0.019 & 0.046 \\
& SED & 0.638 & $\#$ \\
\hline
\end{tabular}

Table 2: Foliar K dry matter concentration (\%) and fruit length for KP variety in 2013-14.

\begin{tabular}{llll}
\hline Year & Treatment & Foliar K (\%) & Fruit length (mm) \\
\hline \multirow{2}{*}{$2013-14$} & (1) Control & $0.686 \mathrm{a}$ & $110.93 \mathrm{a}$ \\
& $(2) \mathrm{K}_{2} \mathrm{SO}_{4}$ & $0.756 \mathrm{~b}$ & $113.94 \mathrm{~b}$ \\
& $(3) \mathrm{K}_{2} \mathrm{SO}_{4}+\mathrm{FA}$ & $0.704 \mathrm{a}$ & $113.63 \mathrm{~b}$ \\
& p-value & 0.036 & 0.031 \\
& SED & 0.022 & 1.373 \\
\hline
\end{tabular}

